\title{
21 世紀の緩和医療
}

\begin{tabular}{|c|c|c|c|}
\hline 川 恵-112) & 哲 ${ }^{2)}$ & 村上 & 忠 $^{213)}$ \\
\hline (左藤嘉代子'2)5) & 梅内美保子'25) & 大友 & $\mathrm{f}^{12}$ \\
\hline
\end{tabular}

〈要＼cjkstart約〉 がん治療率の改善は，がん患者の増加やその高齢化に追いついてはおらず，がんによる死亡率 は増加傾向にある.これに伴い, がんの緩和医療はさらに重要性を増している.

WHO では，緩和ケアを「治癒を目的とした治療に反応しなくなった患者に対する積極的で全人的なケア であり, 痛み, その他の症状のコントロール, 心理面, 社会面, 精神面のケアを最優先課題とする. 緩和ケ アは，疾患の早い病期においても，がん治療の過程においても適用されるべきである.」と定義しているが, 東大病院での医療者に対するアンケート結果からは，その普及は明らかに不十分であることが伺える．この 原因としてとくに緩和医療に関する卒後教育の欠落などがあげられるが, 来年度からの新臨床研修体制のな かには「緩和・終末期医療」が組み込まれており，今後に期待したい.

一方, 緩和ケア病棟や緩和ケアチームなど, 行政側からの働きかけがあり, 受け皿は整備されつつあるが, 今後, がん性疼痛の WHO 方式のコントロール方法, サイコオンコロジーの考え方などが普及していくこと が重要である．また，これまでは治療方法がなくなった時点で緩和医療へ移行する例が多く見られたが，が ん診断の当初から治療と並行して緩和ケアを開始し，末期になるに従い治療よりも緩和ケアの比重を高くし ていくべきであり，末期であっても緩和的がん治療の可能性を捨てるべきではなく，とくに緩和的放射線治 療の重要性を強調したい。

緩和医療は，アングロサクソン諸国で発達した医療の考え方である。もちろん人種を越えた普遍性を持つ ものであるが，その実践においては，社会的，文化的背景を無視できない，今後，日本人の死生観や社会構 造に根ざした「日本型緩和医療」が確立されるべきであろう。

Key words : 緩和医療, 緩和ケア, 終末期医療, 緩和ケア病床, 緩和ケアチーム

(日老医誌 $2004 ； 41 ： 16-22$ )

\section{はじめに}

がんが日本人の死因のトップとなった 1981 年から, すでに 20 年以上が経過した. 高齢化の進行とともに, がん死亡率は伸び続けており，10 年後には総死亡の半 数近くにまでのぼると予想される．また，がん患者の高 齢化も進んでいる．1996 年の年齢別の胃がん，肺がん の䍜患率をみると, 部位別罹患率の 1,2 位であるこれら のがんが，高齢まで増加し続けていることが分かる.

Palliative medicine of the $21^{\text {st }}$ century

1）Keiichi Nakagawa, Kuni Otomo：東京大学医学部附 属病院放射線科

2) Keiichi Nakagawa, Tetsu Iwase, Tadashi Murakami, Yuichiro Saito, Kayoko Sato, Mihoko Umeuchi：同 緩 和ケア診療部

3) Tadashi Murakami：同 精神神経科

4) Yuichiro Saito：同 麻醉科

5) Kayoko Sato, Mihoko Umeuchi：同 看護部
一方，がん治療成績は着実に向上しており，がんに罹 患した患者のおおよそ半数が治癒できるようになってき た。しかし，治癒率の伸びは，がん患者の伸びに追いつ いてはいないので，がんで死亡する患者は増加する一方 で, 社会問題ともなっている.

世界保健機関（WHO）では，緩和医療を,「治癒を目 的とした治療に反応しなくなった患者に対する積極的で 全人的なケアであり, 痛み, その他の症状のコントロー ル, 心理面, 社会面, 精神面のケアを最優先課題とする. 緩和ケアは, 疾患の早い病期においても, がん治療の過 程においても適用されるべきである.」としているが, これは本来, 悪性腫痬だけを対象とするものではない。 しかし, 現実的には, 緩和医療, 終末期医療の典型的対 象は, 悪性腫瘍患者と言ってよい。これは, 患者の苦痛 が激しいこと, 罪患期間が比較的長いこと, 治療方法が ないことが明らかとなってから後の期間が長いこと, 患 者の意識が清明であることが多いこと, 患者数が多く, 
だれでもが他人事と思えないことなどが理由であろう. とくに, がんの治療は, その多くの場合, 初回治療がす べてと言ってよいことに大きな特徴がある．近い将来， がん死することが予想される患者が，全く症状を示さな いことは多く経験されることである．この場合には，緩 和医療の出番の時期は, 告知内容によるが, いずれ必要 になってくることにかわりはない．緩和医療が社会的に も多くの議論を呼ぶのは，それが,「死は不可避である」 という人生最大の問題を強く認識させるからであろう.

筆者等は, 東京大学医学部附属病院（東大病院）で, 緩和医療を担当している．急性期医療を代表する東大病 院でも, 緩和ケア病床, 緩和ケアチームを傘下に置く「緩 和ケア診療部」が発足していることは, 同院の過去の実 情を知る筆者（中川）には，感慨深いものがあるが，そ の活動は今まさに緒に着いたばかりである、本稿では, わが国の緩和ケアの現状を整理し, その問題点を整理し, 21 世紀の緩和医療を展望したい。

\section{緩和医療の現状と展望}

1. 緩和医療を取り巻く背景と問題

（1）医療者の意識

東大病院緩和ケア診療部が, 院内の医師, 看護師を対 象に行った, 緩和ケアに関する調查の結果を以下に示す. 緩和ケア普及/緩和ケアチームの必要性

院内に緩和ケアを普及させることが「非常に必要」「必 要」「どちらかといえば必要」と感じている者は医師の 92.6\%, 看護師の $93.1 \%$ となった。 また緩和ケアチーム を必要としているかについては「非常に必要」「必要」「ど ちらかといえば必要」とした者が医師の $81.4 \%$, 看護師 の $91.1 \%$ となった。

疼痛緩和に関する知識

$\lceil\mathrm{WHO}$ 式がん疼痛治療法」を知っているかどうかに ついて,「内容をよく知っている」「内容をある程度知って いる」と答えたものは医師の $38.5 \%$ ，看護師の $21.3 \%$ であった。

終末期がん患者のケアに対する困難感

終末期がん患者のケアに関して困難を感じているかど うかについて，医師は「非常にある」「よくある」「時々あ る」が $81.5 \%$, 看護師は「非常にある」「よくある」「時々 ある」が $90.9 \%$ であった。 その具体的な内容について， 医師の回答では「病院の体制が十分でないこと」「家族が 満足できるような最期の看取りができないこと」「医療者 同士でのコミュニケーション不足」の順で多く，看護師 は「症状緩和に関する自分自身の知識・技術の不足」「病 院の体制が十分でないこと」「医療者同士でのコミュニ
ケーション不足」の順で多い結果となった.

全体として，東大病院における緩和ケアは十分でない と認識し, 普及の必要性を感じている者が多く, 緩和ケ アサービスに対するニーズは高いということが明らかに なった，緩和ケアチームに依頼したいことの内容は, 症 状マネジメント, 患者の精神的サポート, 療養の場の相 談やコーデイネートと多様であり，緩和ケアチームに幅 広い活動が求められている事がわかった。その中でも, スタッフがケアの困難感として「病院の体制が十分でな いこと」を挙げている．急性期医療が中心の病院である ことが影響していると考えられるが，緩和ケアチームの 活動の中でも療養の場の相談やコーデイネートをサポー トできるようになることが優先されると考える.同じく， スタッフは「医療者同士のコミュニケーション不足」に よってもケアが困難になっていると感じている点も見逃 せない.

(2) 告知の非タブー化

1996 年に東大病院で開催した「東京大学公開フォー ラム 終末期医療を考える, 緩和医療の提唱一進行癌 とどこまで闘うか一」では，告知の是非が議論になって いたが，今，非告知派は少数となった。一般国民の $72 \%$ が告知を希望しており，ほぼ全員が担当医から直接説明 を受けたいと思っている。このことを医療者は忘れては ならない。一方,「末期医療に関する意識調査など検討会 報告書」(厚生省健康政策局総務課, 以下, 検討会報告書) によると，病名や病気の見通しについて，まず誰に説明 するかについては，医師では「患者の家族に説明する」

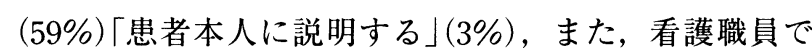
も「患者本人に説明する」(4\%) という回答であった。

このように，国民のほぼ全員が医師から直接説明を受 けたいと望んでいるが, 医師が先ず説明する人としては, 通常では患者本人ではなく患者の家族に説明しているの が現実である，欧米では，医師は，患者本人のプライバ シーに関わる事項についてはそのプライバシーを尊重 し, 通常本人以外に説明することはないが, 我が国では, 医師は告知により患者が受けるであろう精神的な苦痛に 対して配虑を行うとともに，患者本人と家族の一体的な 紏が比較的強いことから，医師は先ず患者の家族に説明 するといったように，いずれ患者本人に説明するとして も家族の意向を尊重するといった傾向を示している。こ のような傾向を示し，医師がまず患者本人に説明できな い一つの理由としては, 告知に関して患者本人との意思 疎通を図る手法に必ずしも医師が習熟していないため, 告知を行うことについて医師側に心理的抵抗があるもの と考えられる。 
一方，患者との意思疎通を図ることを重視している緩 和ケア病棟の医師については, 先ず「患者の家族に説明 する」との回答が $40 \%$ あるものの, 「患者本人の状況を 見て患者に説明するかどうか判断する」との回答が $48 \%$ である。今回調査対象となった緩和ケア病棟に従事して いる医師数は約 50 人と少ないものの, 緩和ケア病棟に おける活動は今後の末期医療の取り組みの流れを示唆し ていると考えられ，一般的な医師においても今後このよ うな取り組みの方向へ変化していくことが予想される.

患者や家族に納得のいく説明を行うには, 患者に対す る適切な説明の他, 患者に対して十分な説明ができる時 間や患者のプライバシーへの配慮された場所の確保など の環境を整備していくことが必要である.現実には,カー テンだけで仕切られた大部屋で, 医師が一人で早口で告 知をして去っていき，患者は同室の別の患者に慰められ る，といったケースが後を絶たない. 患者に対して告知 するにあたっては，医師は患者の意志に配慮すると共に 患者の告知による影響を考えずして一律に告知すること は避けるべきであり, また, 告知後の患者に対する精神 的支援が重要である. 医療者は患者との意思疎通を図る 手法や告知後の患者の精神的支援を図る手法を修得して おくことが必要である.

（3）治療方針の自己決定とインフォームドコンセント 同検討会報告書によると, 患者が治る見込のない病気 に罹患した場合その治療方針を決定するに当たり，先ず 誰に意見を聞くかと言うことに関しては，医師，看護職 員において,「患者本人の意見を聞く」と言う回答率は低 く $(9 \% ， 16 \%)$,「患者本人の状況を見て誰にするかを判 断する」という回答が過半数であった $(55 \%, 71 \%)$. さらに，医師においては，それに続いて「家族に聞く」 (35\%) であった. 多くの医師は患者の意志を重視して いるものの, 先ず患者本人の意見を聞く状況に至ってお らず，現場において患者の状況をみて悩みながら対応し ているのが現状である.

一方，検討会報告書によると，単なる延命医療を続け るべきか中止するべきかについて，患者と医師との十分 な話し合いが行われているかということに関しては，国 民，医師，看護職員において「不十分と思う」または「行 われているとは思わない」という回答が過半数を超えた (53\%，76\%，67\%). 又「行われている」という回答は $10 \%$ 前後であった。

尊厳死協会に自分の「リビングウィル」を登録する人 は，1990 年には数千人であったが， 2002 年には 10 万人 を突破した。このように, 終末期の治療方法の決定を自 ら行いたいと考える人が多い.「先生にお任せします」と
41巻 1 号 $(2004: 1)$

言いながら, 患者本人が, 明確な意志をもっていること も多いものである，治療方針の決定については，患者本 人に適切に告知されているならば，基本的には患者本人 の意見を聞くことによってその決定が可能となる．より 適切な医療を続けようとするならば, 患者の意志や状況 に配慮しつつ, 何れかの時期に, 患者本人に対して病名 等の告知を行っておくことが望ましい.

（4）病院死の増加と緩和ケア病床, 在宅ケア

1950 年代までは，世界的にみても，自宅で死亡する ことが一般的であった。しかし，わが国では，1970年 ごろから病院死が急増し, 1975 年ごろには在宅死を上 回った. 現在,「病院での看取り」が $90 \%$ に達し, とく にがんでは，93\%にのぼる.

一方, 前述の「末期医療に関する意識調查など検討会 報告書」によると，国民が自分自身の問題として痛みを 伴う末期状態となった場合どこで療養生活を送りたいか の質問に対して，11.8\%が「今まで通っていた病院に入 院」, $20.7 \%$ が「緩和ケア病棟に入院」, $20.4 \%$ が「自宅 で療養して必要があれば今まで通った病院に入院」, $28.3 \%$ が「自宅で療養して必要があれば䋸和ケア病棟に 入院」, $9 \%$ が「在宅で最後まで療養」, $4.4 \%$ が「専門 的医療機関で積極的な治療」と回答している. 約半数の 国民が緩和ケア病棟を希望することが明らかとなった 他，およそ6 割がなんらかの在宅でのケアを希望してい ることも注目される。

緩和ケア病棟は， 1 人あたりの面積が広く（病室面積 $8 \mathrm{~m}^{2}$ 以上), 医師が常時勤務し, 看護師の人員配置が厚 い（患者 1.5 人に 1 名配置）などの条件のもとで, 特殊 な診療報酬が設定されている。平成 15（2003）年 10 月 現在 121 施設, 2,310 床が施設基準を満たす緩和ケア 病床として存在する。しかし，上記の国民の希望を満た すには, 現在の 4 倍の緩和ケア病棟が必要とされる.

在宅ケアへの国民の要望は強い。実際, 病院で行える ことの多くが在宅で可能となってきている. また, 在宅 医療における終末期医療に対して, 相応の診療報酬項目 （在宅末期医療総合診療料）もある.しかし,「検討会報 告書」によると, 実際に「在宅で最後まで療養」が可能 と考える国民は，16\%にとどまる．理由として，往診 医の不足, 介護者, 居住環境, 経済的問題など, 医療以 外の生活全般に関わる事項があげられる，行政側の施策 にも期待したい部分である。

東大病院では, 特別病棟のうち 4 床を緩和ケア病床と して, 運用している. 対象は, 緩和ヶア病床のスタッフ が面接により入院の必要性を認めた終末期癌患者で, 以 下の基準を満たすものである。 
＜緩和ケア病床入院適応基準 $>$

1. 患者および家族が緩和ケアに同意し，緩和ケア病 床入床を希望していること。

2. 患者自身が自分の意志を第 3 者に対して十分に表 現できると認められること.

3. 患者が病名・病状について理解していることが望 ましいが，理解していない場合には，患者の求めに応じ て, 適切な病名・病状の説明がなされることを家族が了 承していること.

4. 申し込み診療科の受持・当直体制で患者を診療し, 緩和ケア病床のスタッフと協調して診療を進めること.

5. 検査，処置などは最小限にとどめて，患者の $\mathrm{QOL}$ を優先すること.

6. 申し込み診療科の受持医は, 緩和ケア病床カンファ レンスに参加すること.

2001 年 9 月から 2003 年 10 月までに, 55 名の入院, 死亡退院 46 名, 退院 4 名, 転棟 1 名, 4 名入院中. 平 均在院日数は 46 日（最短 2 日, 最長 272 日）である. 紹介科は, 放射線科 19 例, 消化器内科 9 例, 肝胆膵外 科 7 例，胃食道外科 5 例，耳鼻科 4 例，大腸肛門外科 2 例，神経内科 2 例，脳神経外科 1 例，小児科 1 例，女性 外科 1 例, 循環器内科 1 例, 呼吸器外科 1 例, 泌尿器科 1 例, 呼吸器内科 1 例と多岐にわたった。

（5）一般病床での緩和ケアと緩和ケアチーム

前述のように, 緩和ケア病棟の絶対数は不足している が，さらに問題なのが一般病床での緩和ケアの実践レべ ルの低さである．これを解決する一端として，2002 年 4 月に緩和ケア診療加算が新設され，緩和ケアチームに よって悪性腫瘍患者に症状緩和が提供された場合，入院 基本料に 250 点（1 日につき）が加算されることになっ た。東大病院では平成 15 年 5 月に緩和ケア診療部が新 設され，同時に緩和ケアチームを結成，緩和ケア診療加 算に向けて準備活動と実際のサポートを開始している. 緩和ケアチームとは緩和ケア病棟承認基準を満たした病 棟を持たない施設などで，緩和ケアに関する専任のス タッフがチームとして緩和ケアを提供する形態をいう。 厚生労働省による緩和ケアチームの基準は, 医師 2 名(う ち 1 名は専従）および専従看護師 1 名となっている.こ の 2 名の医師は, 身体症状の緩和を担当する常勤医師と 精神症状の緩和を担当する常勤医師で構成され, どちら か 1 名は, 業務の $100 \%$ をチームの活動にあてる (専従) ことになる.このチームには精神科医師を必要とするが, これは行政側が，緩和医療における，全人的苦痛のケア の必要性を認めたことであり，極めて重要である．緩和 医療における精神面の問題は，後で別項で触れる.
今回，東大に新設された緩和ケアチームががん患者の QOLの改善に役立っているかどうかを, STAS（The Support Team Assessment Schedule）を用いて検証し た. その結果, ペインコントロール, 症状コントロール, 患者, 家族, 医療スタッフの distressについて介入効果 を 20 例でみた結果, ペインコントロール, 症状コント ロールでは明らかな改善を確認した.

（6）学部教育, 卒後教育

医学生を対象としたアンケートによると約 $60 \%$ が緩 和ケアに関心を持つとされる．2000 年度の全国 67 大学 からの回答でも，緩和ケアに関する講義があるのは 63 校 $(94 \%)$ にのぼる。なお，1994 年，1997 年の調査で はともに $50 \%$ 以下であった。講義名称は, 緩和医療 $13.9 \%$, ターミナルケア $13.9 \%$, 医療概論 $13.9 \%$, 緩和 ケア $10.9 \%$, 終末期医療 $9.9 \%$, 疼痛緩和 $7.9 \%$, 麻酤/ ペインクリニック $6.9 \%$, 総論/総合講義 $6.9 \%$, ほかで ある. 東京大学医学部医学科でも，6年生を対象とした 「緩和医療学」の講義が 2 コマあり, 筆者の一人（中川） が担当している. がん患者さんに来て頂き, 生の声をき いてもらったり, 学生間で, ロールプレイをしてもらっ ている.この他, 放射線科実習のなかで, 緩和ケア病床 の見学などを組み达んでいる.

このように, 緩和医療についての医学部教育はある程 度，充実しつつあると言える，一方，卒後教育について は, 改善の余地が多い. 前述の東大病院における緩和ケ アに関する調查の結果でも, WHO 式がん疼痛治療法の 「内容をよく知っている」,「内容をある程度知っている」 医師は 38.5\%にとどまっている，また，大学病院での 死亡患者数が少ないことも問題である. 99 年の 40 大学 の死亡数と病床数との比は 12,529 人 (死亡数) $/ 34,314$ 床 $($ 病床数 $)=0.365$ で, 一般教育病院の 0.703 と比べて 半分程度である。

来年から始まる新臨床研修体制のなかの「特定の医療 現場の経験」には「緩和・終末期医療」が組み込まれて おり，以下の目標と必修項目が指定されていることは評 価できよう。

緩和・終末期医療を必要とする患者とその家族に対し て，全人的に対応するために，

1）心理社会的側面への配慮ができる.

2）緩和ケア（WHO 方式がん疼痛治療法を含む）に 参加できる.

3）告知をめぐる諸問題への配慮ができる.

4）死生観・宗教観などへの配虑ができる. 必修項目 臨終の立ち会いを経験すること

2. 緩和医療の実践と展望 
$41: 20$

（1）疼痛緩和の指針と拡がり

疼痛緩和の第一歩は全人的な痛みと捉えることであ る. 全人的な痛みへの対処は身体的・精神的・社会的・ スピリチュアルという 4 つの側面からアセスメントし対 処することが必要不可欠である.身体的苦痛については, とくに原因の探査が重要である.

身体的苦痛への対処については，まず，薬物療法であ るが, WHO の 3 段階除痛ラダーに示されているように， 痛みの程度が軽度の場合，非オピオイド製剂と鎮痛補助 薬の併用を試みる．中等度の痛みに対してはそれに弱才 ピオイドを加える．さらに高度の痛みに対しては強オピ オイドを使用する．ただし，常に痛みの第 1 段階からの 投薬を開始するのではなく，必要であれば，初めから第 2 , 第 3 段階の鎮痛薬を投与する．非麻薬性鎮痛薬には非 ステロイド性抗炎症薬, アセトアミノフェン,ブトルファ ノール，ペンタゾシンなどがあり，弱麻薬性鎮痛薬には リン酸コデイン，ブプレノルフィンなどがあり，そして 強麻薬性鎮痛薬にはモルヒ六製剤，フェンタニル製郕が ある，麻薬の副作用（便秘，嘔気嘔吐，眠気など）への 対策も重要で，これを怠ると患者が麻薬の使用を拒み， 疼痛コントロールが難しくなる。

しかし，強麻薬製剤によっても十分な鎮痛が得られな い場合がある．それぞれには対処法がある，骨転移によ る痛みには放射線療法, ホルモン療法, ステロイド療法, 神経ブロック療法などが有効で，筋攣縮による痛みには 筋弛緩薬，マッサージ，トリガーポイントブロック療法 などが有効, 神経因性の痛みには抗不整脈薬, 抗うつ薬, 抗不安薬, 抗痙攣薬, NMDA 受容体拮抗薬, ステロイ ド剂などが有効である，交感神経関与の痛みには胸部や 腰部の交感神経ブロック，腹腔神経叢ブロック，下腸間 膜動脈神経叢ブロック，上下腹神経叢ブロックなどが有 効である．消化管の収縮拡張による痛みには排便コント ロール，緩下薬，鎮痓剤，硬膜外ブロックなどが有効で ある．頭蓋内圧六進による頭痛にはステロイド郕や脳圧 降下薬などが有効である。このように，鎮痛手段には多 くの選択肢がある，そのため，各治療段階での選択が重 要になってくる．緩和ケアに扔ける一般的な鎮痛剂とし てのモルヒネ製剤も以前と比べてその剂形（坐剂，カプ セル，細粒，液剂)，投与経路（経口，静注，皮下注， 経管，坐剂）など新しくなってきている，さまざまな徐 放製剂の登場で日本でのモルヒネの使用量は年を追う毎 に増えてきている．また，フェンタニル貼付製郕の発売 により，長時間（72 時間）の鎮痛も可能になってきて いる．日本にはまだ欧米のように多くのオピオイド製剤 があるわけではないが，症状や副作用をみながらオピオ
41巻 1 号 $(2004 ： 1 ）$

イド製剤の変更を行うというオピオイドローテーション という考え方も徐々に浸透してきている．現時点ではオ キシコドンとモルヒネとフェンタニルでの選択が可能で ある。

（2）サイコオンコロジー

サイコオンコロジーは，がんを抱えた患者のこころの 問題を取り扱う学問領域である. かつて，がんが不治の 病であった時代には，がんはすなわち “死”であり，医 師はがんを抱えた患者と正面から向き合うことを避けて いたといってもよい状況があった。がん細胞を撲滅する ことが医療の至上命題として掲げられ，19 世紀には一 部のがんで外科的手術が可能となった。 その後, 麻醉や 手術技術の発達に加え，20世紀に入るとさらに放射線 治療, 化学療法が導入され, 様々な臓器のがんに対する 治療は現在まで飛躍的進歩を続けている。こうした中， 病名告知を含むインフォームド・コンセントの問題や QOL（quality of life）の概念がクローズアップされる情 勢を背景に，米国ニューヨークのスローン・ケタリング 記念がんセンターに精神科部門が設置され，リエゾン精 神科医のジミー・ホランド博士が部長に就任し，がん患 者に対する心理・社会的な治療および研究を始めたのが サイコオンコロジーの端緒とされている。これは 1977 年，今からわずか 25 年あまり前のことである.

我が国では，1980 年代から淀川キリスト病院をはじ めとしたホスピスで精神科医が活動を始めているが，す べてのがん患者がサイコオンコロジーの恩恵にあずかる にはほど遠い状況が続いていた，厚生労働省が緩和ヶア 診療加算を新設し，精神科医を含むチーム医療をその必 要条件としたことで，こうした状況は大きく変わりつつ ある。この診療加算により，患者は早期からがんの治療 と並行して，心理・社会的あるいはスピリチュアルな問 題について，サポートを受けることができるようになっ た。また，患者だけではなく，患者を抱えた家族もその 対象とされている.

医療はとかく「病」そのものに向かいがちであるが， サイコオンコロジーは病を抱えた「人」をみる学問であ るとも言える．治療成績が日々向上しているとはいえ， 現在も国民のおよそ 3 人に 1 人はがんで亡くなってい る.がんという病がこころに与える影響は非常に大きな ものであり，この領域における精神科医への期待はます ます高まっている，今後 21 世紀には，がんの治療成績 のさらなる向上とともに, 神経免疫学や内分泌学などと 連携し, 心理・社会学的側面だけでなく，精神生物学的 側面にも焦点を当てたサイコオンコロジーの発展が求め られている。 
（3）がん治療体系と緩和医療

「はじめに」でも述べたように，世界保健機関（WHO） では,「緩和ケアとは，治癒を目的とした治療に反応しな くなった患者に対する積極的で全人的なケアであり，痛 み，その他の症状のコントロール，心理面，社会面，精 神面のケアを最優先課題とする。緩和ケアは，疾患の早 い病期においても，がん治療の過程においても適用され るべきである.」として,がんの緩和医療とは,「がんの 診断から終末期までの全過程におけるQOLを重視した 医療」というとらえ方を提唱した。この考え方は，がん の緩和医療のあり方を変貌させるとともに，がんの診療 体系にも大きなインパクトを与えつつある.

緩和医療側からみると，終末期あるいはその前のある 特定の時期に「がん治療」から「緩和ケア」に移行する のではなく，がんと診断された当初から治療と並行して 緩和ケアを行い，末期になるに従い治療よりも緩和ケア の比重を高くするべきという考え方への移行である．初 期の緩和ケアは, 従来の延命重視のがん治療へのアンチ テーゼ的面を持っていた。このため，前医では，抗がん 片治療を受けていた患者が，ホスピスへ転院するなり， 一切の治療行為を中止して，ケアだけを受ける，といっ た事例がよく見られてきた。しかし，末期がんでも抗が ん治療が意味を持つことは多い．骨転移による疼痛をモ ルヒネで抑えることはできる．しかし，椎体転移の増大 による脊檤麻瘏, 四肢骨転移で病的骨折, 脳転移による 各種神経症状などは，末期がん患者の QOLを一気に悪 化させる。こうした転移病巣の制御に最も有効なのは放 射線治療である，筆者は，放射線治療を行えることが，

一貫性のある緩和医療に不可欠と考えている.

がんの治療体系に対して，緩和医療の考え方が与える 影響も無視できない.これまで根治的がん治療の優劣は, 生存率によって判断されてきた。これに対して, 緩和医 療では, 副作用や後遺症, 精神的苦悩を含めた患者の QOL を重視し，生命を維持できる時間の長さそのもの にはあまりこだわらない。そもそも，根治治療と言って も，人間である患者には長くても高々 100 年の時間しか 与えられないのであり, 根治治療も緩和治療も相対的差 しかないはずであろう．緩和医療の考え方に立てば，十 分にインフォームドコンセントを受けた患者が，非根治 的治療を選択することはあり得ることであり，とくに， 高齢者では，すでに日常的になっている. 現在, がん治 療における $\mathrm{EBM}$ が花盛りであり，筆者等もこれに基本 的には賛同するが，緩和医療は，これに患者の意志によ る一定の幅を与えることになると考える。

（4）日本型緩和医療の確立へ
緩和医療は，アングロサクソン諸国で発達した医療の 考え方である。もちろん人種を越えた普遍性を持つもの であるが，その実践においては，社会的，文化的背景を 無視できない．英国，米国，カナダにおいてすら，その 在り方には差があるのであって, 日本の緩和ケアは, 緩 和ケアユニットが中心のカナダに最も近いとされる.

米国で死にゆく人たちの精神状態を研究したエリザベ ス・キュブラー・ロスは, 人間は, 死に直面したとき,「否 認」怒り」「取り引き」「うつ」という段階を経たのちに， 死を「受容」すると言っている，ロスの著書からは,「確 固たる自我を持つ人間が，外からやってくる『死』を拒 絶し, 対決し, 克服し, 最終的に受け入れる」という流 れが感じられるが，こういう考え方は，多分に契約とキ リス卜教を基盤とする欧米的であり,とくに,「死の受容」 は日本人にも見られるとしても，欧米のそれとは多少意 味が違うように思える。それは，むしろ「自然に帰る」 というイメージに近いのではないか. 実際, 存在の純粋 な消滅として死を受容しつつ亡くなる患者は多くはな い.

ある研究によると,「あなたはどんな環境で死にたいで すか？」という質問に，日本人の多くは「自然の風景を 見ながら」と答えたそうである.「花の下にて春死なむ」 と詠んだ西行から，全く変わっていないのだから，日本 人の自然回帰は根元的な無意識なのであろう。こうした 点で，終末期を迎える日本人にとって，家庭とともに， 自然は最良の治療環境と言えよう。日本の緩和ケア施設 の多くが，自然環境に恵まれた場所にあるのは，理由の あることかもしれない。

いずれにせよ，キリスト教や仏教などの明確な宗教の 力を借りずに，立派に死を迎える患者が大半なのも事実 である。これが，あの世や自然とのつながりといった， 日本人の共通の宗教的世界観からか,「生きざま主義」の おかげか, あるいは人間が本来持っている精神的力のせ いかは分からない，しかし，問題は，残り少なくなる生 の時間とひきかえに次第に強まっていく患者さんの実存 的問題に対して, 医療者が無関心なことであろう. 欧米 のシステムをよく学んだ上で日本流にアレンジすること が得意な日本人のことだから, 近い将来,「日本型緩和医 療」が確立されることを筆者は疑わない。

\section{文献}

1）E. キューブラー・ロス（川口正吉訳）：死ぬ瞬間。読売 新聞社, 1971.

2）フィリップ・アリエス：死と歴史一西欧中世から現代 へ. みすず書房, 1983. 
3）厚生省・日本医師会編：末期医療のケア. 中央法規出版, 1989.

4）千原 明：「全国ホスピス・緩和ケア病棟連絡協議会」 の歩みと展望. ターミナルケア編集委員会 (編), ホス ピス・緩和ケア白書. ターミナルケア 1998;8(suppl.)： $44-46$.

5) World Health Organization: (1990). Cancer pain relief and palliative care: Report of a WHO Expert Committee. Geneva : World Health Organization. (武田文和訳, (1993)).

6）がんの痛みからの解放（第 2 版）：世界保健機関編（武 田文和訳)，金原出版，1996.

7） 21 世紀の末期医療：厚生省健康政策局総務課監修, 中 央法規出版, 2000 .

8）厚生労㗢省・日本医師会, 日本ホスピス・緩和ケア研究 振興財団：がん緩和ケアに関するマニュアル，2002.

9）ホスピス・緩和ケア病棟の現状と展望：厚生科学研究
「緩和医療供給体制の拡充に関する研究」班，2001.

10）がん疼痛治療ガイドライン：日本緩和医療学会がん疼痛 治療ガイドライン作成委員会編, 真興交易（株）医書出 版部, 2000.

11）恒藤 暁: 最新緩和医療学. 最新医学社, 1999.

12）清水哲郎：QOL の基礎理論. 日本緩和医療学会(監修), 柏木哲夫, 石谷邦彦 (編), 緩和医療学, 三輪書店, 東 京, 1997, pp. 238-243.

13) Doyle D, Hanks GWC, MacDonald N (Eds.) : Oxford Textbook of Palliative Medicine (2nd ed). New York: Oxford University Press, Inc.

14) Higginson I (Ed.) : (1993a). Clinical audit in palliative care. New York : Radcliffe Medical Press, Inc.

15) Hearn J, Higginson IJ : Do specialist palliative care teams improve outcomes for cancer patients? A systematic literature review. Palliative Medicine $1998 ; 12$ : 317-332. 